\title{
Mechanical and Industrial Engineering: Multidisciplinary Partners in the Freshman Design Experience
}

\author{
Linda Ann Riley, Edgar Conley \\ Department of Industrial Engineering/Department of Mechanical Engineering \\ New Mexico State University
}

\section{Introduction}

A discipline-specific freshman design course is a common offering in many engineering programs. Typically, this introductory class has several objectives:

1) To excite and motivate students about engineering in general, and further, to foster enthusiasm about a discipline-specific field such as mechanical or industrial engineering;

2) to provide students with elementary tools and methods useful in the design process and to encourage students to apply these tools by means of carefully crafted design exercises;

3 ) to develop teaming, interpersonal, time management and creative thinking skills;

4) to further refine communication, writing and presentation skills; and

5) to begin the process of relationship building among individual students, the instructor teaching the course, and the student's home department.

From a faculty perspective, achieving these objectives with a group of freshmen may seem daunting. Nevertheless, such a course is often the student's first exposure to discipline-specific material, thus an improperly designed, uninteresting course can negatively and strongly affect engineering program attrition rates.

The precise influence of initial course offerings on attrition is unknown but statistics indicate a problem exists - engineering drop-off rates from the freshman to sophomore year are notable. Even more compelling is the percentage of students leaving one engineering discipline for another, or choosing an entirely different major in another college. This raises the question, what happens during the freshman year? What did the student witness or experience that caused a rejection of an engineering area of first choice? In contrast to the sophomore and junior years, during the freshman year the level of difficulty and technical nature of engineering material is elementary. So the problem we believe, owes not to the sudden increase in academic rigor - it lies in the initial subject matter, its presentation and the student's various interactions with faculty and other students.

Seeking an alternative and/or complement to the traditional engineering-tools freshmen offering, we present the following article. We had two primary goals: 1) reduction in freshman attrition rates; and 2) curricular redesign according to ABET 2000 guidelines. To accomplish these goals, faculty members in the mechanical and industrial engineering departments at New Mexico State University initiated a partnership. The partnership focused on the design and implementation of an innovative approach to captivate relatively inexperienced students early in their engineering 
studies. The new course was positively highlighted and viewed as a strength of the respective mechanical and industrial engineering programs during the ABET 2000 accreditation visit to the College in October, 2000.

\section{Background of the Attrition Issue}

A number of studies measuring engineering attrition rates suggest that between $50 \%$ and $70 \%$ of freshmen starting in an engineering program will not graduate with an engineering degree. In some of the definitive studies on the subject, Astin and Astin ${ }^{1,2,3}$ followed 25,000 engineering students at more than 300 institutions. The Astins found that only $43 \%$ of first-year engineering students ever graduate with a degree in engineering. The Astins also documented statistics concerning students leaving engineering altogether: $40 \%$ left to study in a non-science or mathematics field. In an Iowa State study, Moller-Wong and Eide ${ }^{4}$, found attrition rates at that institution were between 55 and $60 \%$. However, in this case, only $32 \%$ of the students starting in engineering programs actually graduated with a degree in engineering within five years.

Additional research has identified the many reasons students decide not to remain in an engineering program of study. Contrary to popular belief, academic inability is not a primary reason. ${ }^{5,6}$ Instead, the combination of several factors, including lack of faculty interaction with the student, faculty enthusiasm for teaching engineering, classroom experiences, student interest in engineering, and curricula delivery models are but a few of the reasons why students choose an alternate major, or drop out of school altogether. ${ }^{7,8,9,10}$

Attrition rates in engineering at New Mexico State University follow closely the national patterns. Table 1 on the following page shows the retention and continuation rates for the College of Engineering at this institution. This table highlights some interesting points. First, our four-year graduation rate averages only about $4 \%$. This in part is due to the strong emphasis the various engineering programs place on co-op or internship experiences as well as the specific program credit totals required to complete a degree in engineering. Second, after six years, the university has graduated approximately $45 \%$ of the starting freshman in Engineering. What is not exactly clear however, is how many of these students that have graduated actually graduate with a degree in engineering in contrast to graduating with a degree in another major. Last, and most significant, we lose approximately $24 \%$ of students who start in engineering after only the freshman year.

One point that is clear with respect to engineering attrition is the importance of the freshman experience as a mechanism to captivate and engage students in the field of engineering. In addition to two discipline-specific freshmen engineering courses, New Mexico State University students are also required to take Engineering 101. Comprised of many valuable topics, Engineering 101 overviews the university and college and introduces basic engineering principles. But it's taught in a large lecture style format that precludes any opportunity for faculty from specific engineering disciplines to interact with individual students.

Voluminous as it is, the literature suggests no magic formula for creating or providing an optimal freshman experience. Therefore, in view of multiple approaches suggested in the literature and our own teaching experience, we set about to create a multidisciplinary course that addressed College assessment studies in addition to ABET 2000 guidelines. A fun, challenging, hands-on 
project course that strongly encouraged multi-disciplinary team building, problem solving and faculty/student interaction was the result.

\section{Table 1 - New Mexico State University, Main Campus - College of Engineering First-time, Full-time Freshman Cohorts, Fall 1994 - 1999 Retention Rates*}

\begin{tabular}{|c|c|c|c|c|c|c|c|c|c|c|}
\hline $\begin{array}{l}\text { Cohort } \\
\text { Classes }\end{array}$ & $\begin{array}{l}\text { Head- } \\
\text { count }\end{array}$ & $\begin{array}{c}1 \text { year } \\
\text { Retention } \\
\text { Rate }\end{array}$ & $\begin{array}{c}2 \text { year } \\
\text { Retention } \\
\text { Rate }\end{array}$ & $\begin{array}{c}3 \text { year } \\
\text { Retention } \\
\text { Rate }\end{array}$ & $\begin{array}{l}4 \text { year } \\
\text { Grad. } \\
\text { Rate }\end{array}$ & $\begin{array}{c}4 \text { year } \\
\text { Contin. } \\
\text { Rate }\end{array}$ & $\begin{array}{l}5 \text { year } \\
\text { Grad. } \\
\text { Rate }\end{array}$ & $\begin{array}{c}5 \text { year } \\
\text { Contin. } \\
\text { Rate }\end{array}$ & $\begin{array}{l}6 \text { year } \\
\text { Grad. } \\
\text { Rate }\end{array}$ & $\begin{array}{c}6 \text { year } \\
\text { Contin. } \\
\text { Rate }\end{array}$ \\
\hline 1991 & 320 & $77.8 \%$ & $67.2 \%$ & $59.7 \%$ & $3.1 \%$ & $52.5 \%$ & $27.8 \%$ & $30.3 \%$ & $45.6 \%$ & $10.3 \%$ \\
\hline 1992 & 325 & $77.5 \%$ & $63.7 \%$ & $57.8 \%$ & $5.2 \%$ & $49.2 \%$ & $27.1 \%$ & $27.7 \%$ & $44.3 \%$ & $11.4 \%$ \\
\hline 1993 & 312 & $78.8 \%$ & $62.5 \%$ & $58.3 \%$ & $3.8 \%$ & $54.5 \%$ & $33.0 \%$ & $26.9 \%$ & $46.5 \%$ & $12.2 \%$ \\
\hline 1994 & 258 & $77.5 \%$ & $67.1 \%$ & $62.4 \%$ & $5.4 \%$ & $54.7 \%$ & $29.5 \%$ & $32.2 \%$ & & \\
\hline 1995 & 247 & $76.5 \%$ & $64.4 \%$ & $59.9 \%$ & $2.8 \%$ & $53.4 \%$ & & & & \\
\hline 1996 & 275 & $78.5 \%$ & $67.6 \%$ & $62.2 \%$ & & & & & & \\
\hline 1997 & 262 & $80.5 \%$ & $63.0 \%$ & & & & & & & \\
\hline 1998 & 337 & $76.3 \%$ & & & & & & & & \\
\hline
\end{tabular}

* Source: Office of Institutional Research, New Mexico State University, August 2000

\section{ABET Impact on the Freshman Multidisciplinary Design Course}

With the College's decision some four years ago to be evaluated under ABET EC2000 guidelines, a major emphasis since that time for all new curricular design is consideration and integration of the ABET "a through k" expected outcomes of an engineering graduate. We use three primary sources of data to determine and monitor these expected outcomes: national studies, alumni, and employer surveys.

At the national level, a number of studies, white papers and conferences have documented industry and/or individual company input that identify the key attributes that impact workplace success of engineering graduates. Table 2 presents some of the key sources and findings related to each source for industry/employer determinants of engineering graduate success. Our philosophy at New Mexico State University is assure that all of our engineering courses address in part or whole these attributes. This is especially true during the introduction of a course or the redesign of an existing course. 
Table 2

\section{Industry/Employer Determinants of Engineering Graduate Success}

\begin{tabular}{|c|c|}
\hline Source & Key Success Determinants \\
\hline $\begin{array}{l}\text { ASEE Engineering Deans Council } \\
\text { Corporate Roundtable Study }{ }^{(11-12)}\end{array}$ & $\begin{array}{l}\text { In addition to ABET EC } 2000 \text { a through } \mathrm{k} \\
\text { 1. Leadership abilities } \\
\text { 2. Understanding and appreciation of diversity and pluralism } \\
\text { 3. Commitment to quality } \\
\text { 4. Experiences with undergraduate research and internships. }\end{array}$ \\
\hline Koen and Kohli ${ }^{(13)}$ & $\begin{array}{l}\text { 1. Effective problem solving } \\
\text { 2. Use of computers for communication } \\
\text { 3. Ability to develop innovative approaches } \\
\text { 4. Ability to exert high levels of effort } \\
\text { 5. High professional/ethical standards }\end{array}$ \\
\hline Evans et al. ${ }^{(14)}$ & $\begin{array}{l}\text { 1. Problem solving } \\
\text { 2. Communication skills } \\
\text { 3. Ethics and professionalism } \\
\text { 4. Open mindedness, attitude } \\
\text { 5. Math and science skills }\end{array}$ \\
\hline Benefield et al. ${ }^{(15)}$ & $\begin{array}{l}\text { 1. Self-starter, initiative } \\
\text { 2. Technical knowledge } \\
\text { 3. Written communications skills } \\
\text { 4. Oral communication skills } \\
\text { 5. Computer skills for problem solving }\end{array}$ \\
\hline $\begin{array}{l}\text { National Conference on Outcomes } \\
\text { Assessment, industry roundtable }{ }^{(16)}\end{array}$ & $\begin{array}{l}\text { 1. Technical competence } \\
\text { 2. Flexibility } \\
\text { 3. Teaming } \\
\text { 4. Communication skills } \\
\text { 5. Ethics }\end{array}$ \\
\hline Lang et. al. ${ }^{(17)}$ & $\begin{array}{l}\text { 1. Engineering knowledge } \\
\text { 2. Data analysis, interpretation and problem solving skills } \\
\text { 3. Ethics and professionalism, lifelong learning } \\
\text { 4. Communication skills } \\
\text { 5. Teaming skills }\end{array}$ \\
\hline Besterfield-Sacre et. al. ${ }^{(18)}$ & $\begin{array}{l}\text { 1. Technical background, engineering knowledge } \\
\text { 2. Problem solving skills } \\
\text { 3. Communication skills } \\
\text { 4. Organizational and management skills } \\
\text { 4. Teaming skills }\end{array}$ \\
\hline
\end{tabular}

At the College assessment system level, one important objective of the alumni and employer surveys is to assist departments with prioritizing their efforts with respect to developing new, or improving existing courses. Although the two surveys cover many different areas, one section in particular produces a "gap" analysis that has been most useful in directing course redesign.

For example, consider the alumni survey. Using 1 to 5 point Likert scales, our graduates were asked to rate the importance of certain characteristics and skills for their success in the 
workplace. Immediately following this series of questions, respondents were then queried on how well their education at New Mexico State University prepared them for the specific area. By evaluating the two series of questions in unison, a semantic differential scale showing the gap on each item was created. ${ }^{19}$ Our starting point for curriculum redesign addresses the larger gaps first, with the overall intent on narrowing this gap. Figure 1 shows a simple example of a gap analysis at the College level.

\section{Figure 1*}

\section{Gap Analysis - Success Factors Vs. Preparation}

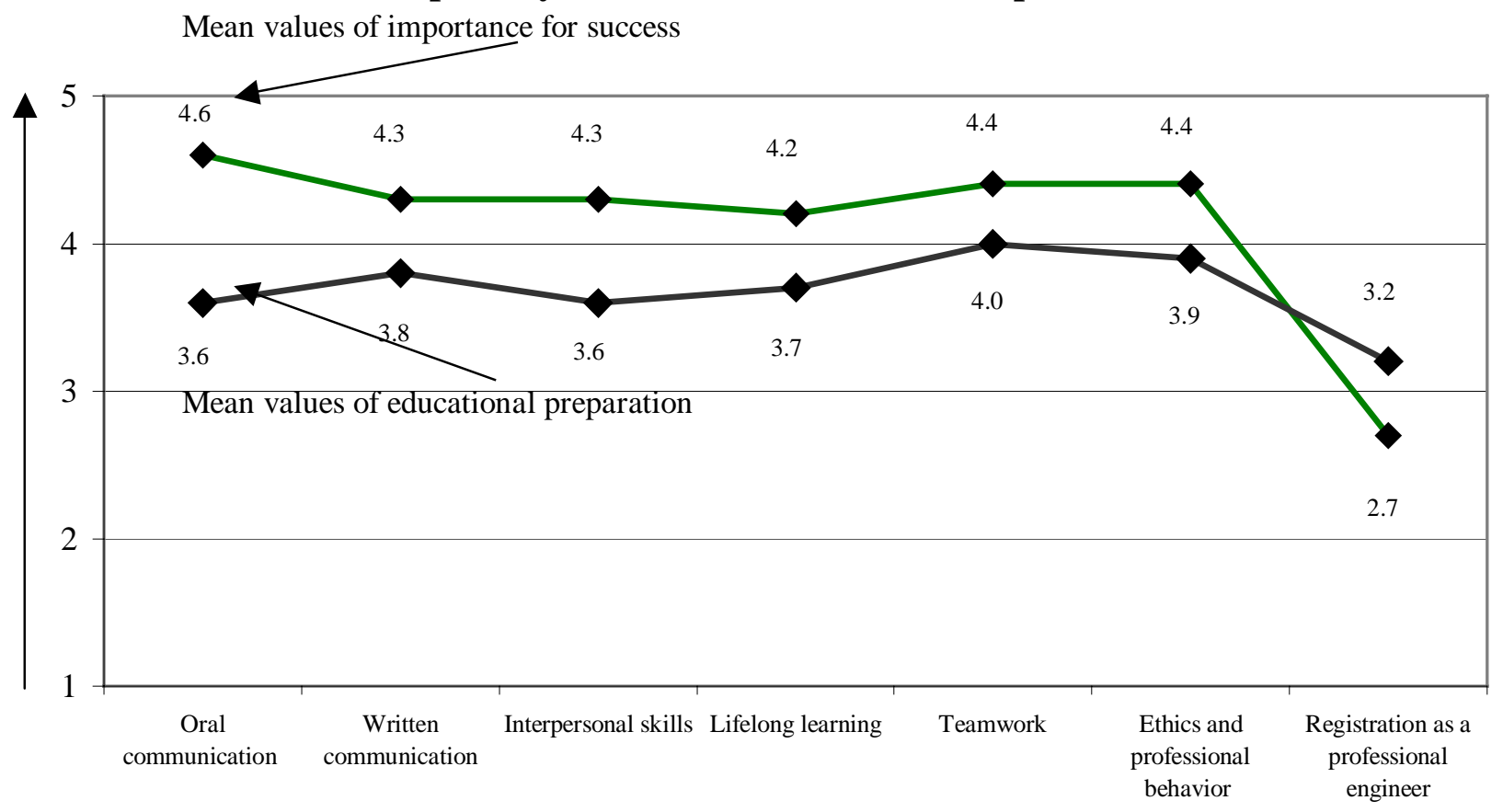

* Source: NMSU College of Engineering Alumni Survey: Summer 1999, represents 162 alumni in both the two and five year cohort groups

Results of the gap analysis show that, of the listed factors, alumni believe that oral communication skills are the most important factor contributing to success in the workplace. Interestingly, alumni also judge communication skills as one of the areas where they received least amount of preparation in their undergraduate program.

From a statistical perspective, there was no significant difference in responses between the twoand five-year alumni groups. However, there was a statistically valid difference on some of the success factors between different departments. Professional registration is an example. With the exception of our Civil Engineering and Surveying Engineering graduates, this factor was not viewed as a major contributor to success. In fact, this is the only item where a negative gap appeared.

\section{Specifics: The Design of the Multidisciplinary Freshman Course}

Armed with the results of multiple assessment instruments, documentation of internal attrition statistics, and taking into consideration our goals, increased retention and ABET a-k outcomes, 
we redesigned the freshman course. The following sections discuss the specifics of the course redesign and the challenges and rewards in adopting the new format.

General - Syllabus - The class joint syllabus overviewed both the IE and ME components of the class as well as ABET-required syllabus information for each of the two engineering disciplines. In detail, the syllabus described course credit awarded in an even mixture of engineering basics and projects $(60 \%)$, with the remaining $40 \%$ based on sign-in attendance plus the final exam. We viewed mandatory attendance as critical to our retention goals. If the students weren't in class, it was not possible to interact and start the process of relationship building. Furthermore, with the heavy emphasis on IE/ME team projects, class attendance was at least one opportunity to meet with other group members to discuss and develop the projects.

Engineering Tools - The engineering tools part of the course stressed some fundamentals. We began the term with a patent search series of labs that focused on the exploration of the student's impression of a "clever" engineering design. In addition to the basics of studying engineering patent drawings, search and retrieval techniques, and the various types of patents, the exercise also served to introduce a surprisingly large percentage of freshmen to the college computer and email systems. A small percentage of our classes focused on discipline specific engineering tools. For example, in a couple of class during the semester the mechanical engineers studied gears, bolts and 4-bar mechanisms while the IE students explored process improvement strategies using such tools as Lego activities and simulation.

Project design - We expended considerable effort in creating project assignments that contained the 'right' assortment of task planning, logo design, hands-on fabrication, testing, and report writing. The assignments were undertaken in teams consisting of both mechanical and industrial engineering students and in all cases stressed informal and formal communication skills. As with any design class, the problem was to assign projects that interested and engaged all team members. This meant that special attention had to be directed to include mechanical and industrial engineering tasks that would be assigned to specific team members. The projects had to be inexpensive and simple, of course, and not require the students to use precision machinery. Finally, every major project assignment was evaluated in a head to head performance- based competition between the project groups. The contests were assigned with clear objectives and were carried out with strict adherence to specifications and competition rules.

Over the semester, three major multidisciplinary projects were undertaken. The first project involved manufacturing a puzzle, the second, packaging a 'plutonium' ball, and the third, designing a catapult. Appendix 1 provides the student overview for the catapult design project and Appendix 2 provides the report outline required for the student report submission associated with the catapult design.

Forming multidisciplinary teams - Our intention was to carry on separate classes for the specific ME and IE engineering tools topics, but then, during the project periods, merge the MEs and IEs into multidisciplinary design groups. We found that students seemed to adjust readily when they were assigned to a particular group, but when allowed to select their own design group members, students opted for their in-class neighbor. One of the greatest challenges here was the logistics of the class time as well as nature of the two freshman courses. First, the classes did not meet at the same time; rather they met in back to back time slots. Second, the 
mechanical engineering class carried three credits while the industrial engineering carried only two. As a result, the mechanical engineering class met three times a week whereas the industrial engineering class met twice weekly. Even with this logistics challenge, as the semester progressed, IE students would frequently attend ME classes during project times and conversely ME students would attend the IE sessions since the identical material and assignments were covered in both classes.

Prior to the semester start, we realized that the logistics challenge would be significant. But based on experience with our senior capstone design course, a multidisciplinary course involving industrial and mechanical engineering students as well as technical communications majors from the Department of English, we knew what to expect from this challenge. Also, since this was a pilot test for the course and the lead-time necessary for changing university-scheduling systems was prohibitively long, we were willing to go ahead and attempt this first collaboration. If we deemed the experience a successful one, we intended to address the scheduling issue immediately after the semester ended in preparation for the next joint class almost a year in the future.

Providing motivation - During the middle of the term, and following the completion of a project, a peer evaluation was requested of each student. Each design group member was asked to evaluate his fellow members' contribution to completing the project. The evaluation was to remain confidential, so the form was not collected during the same class period it was handed out, leaving the individual student with a convenient excuse not to divulge his/her evaluation. The forms were later assessed to detect large disparities among individual group members' contribution estimates. We spent a bit more time talking about task assignments with the (surprisingly few) groups that showed a wide range of estimates. These groups seemed to respond and then were able to carry out future projects satisfactorily. As a result of this process, it became evident that additional instructor effort was needed in working with the students on team management, team communication and team building skills. Even of these freshmen, we required a project timeline and plan at the beginning of each new multidisciplinary effort. In addition, we required each team member sign his or her name on the final report for each project. This indicated that the team member felt he or she participated fully to bring the project to completion. This action worked well in light of some of the semester activities focusing on engineering ethics case studies involving individuals taking credit for engineering work that was not their own.

Logbooks - Student logbooks, the purpose of which (we believed) was clearly spelled out in the syllabus, were not utilized to the greatest extent possible. We had asked the students to write a brief description of each class day's activities along with pretty much anything else that popped into the their head. This format obviously provided a great deal of flexibility. The problem, we believe, is that we prescribed no specific structure for entries into this log. On the other hand, the inherent flexibility was intended to provide students with the opportunity to express an opinion or thought they may not otherwise voice. As with other requirements during the semester, students were most comfortable with those assignments possessing a specific structure that precisely articulated what was required of them along with the steps associated with accomplishing those tasks. 
Use of teaching assistants - Due to our desire for extremely high, repeated personal contact with each student in the class, our graduate teaching assistants played an integral role in assisting us to accomplish our retention goals. Teaching assistants collaborated on delivering in-class exercises, worked with teams on project designs, assisted in the supervision of project competitions, worked with students on computer lab exercises and maintained log book check-in records.

\section{Challenges with creating and delivering the multidisciplinary freshman design class}

The greatest challenges in creating and providing a course such as the multidisciplinary freshman experience were the following:

1. Logistics of different meeting times and different credit weights for the two courses.

2. Slightly different departmental objectives with regard to the purpose of the freshman design course.

3. Creating design exercises at a very elementary level that incorporated both mechanical and industrial engineering components.

4. Amount of time required for the two faculty members and two graduate teaching assistants to coordinate all facets of the course including collaborative syllabus, design exercises, grading, etc.

5. Size of the classes - two ME classes with approximately 30 students each, and the IE class with 33 students.

6. Assuring the two student groups (IE and ME) understood each other's field and respected each other's contributions. (This also applied to the faculty teaching the course.)

7. Incorporating a heavy written and oral communications component into the course to begin to address the assessment concerns involving lack of communication preparation for the workplace.

\section{Rewards associated with the experience}

1. We believe that by means of the design of this course, students have gained a much better understanding and appreciation of mechanical, industrial, and more important, a systems' perspective of how these two disciplines work together.

2. Students report that they have enjoyed the course and are satisfied with their respective decisions to study either industrial engineering or mechanical engineering.

3. By means of repeated one-on-one personal contact during the semester, several students that may have been lost (and become attrition statistics) had their specific concerns addressed. Through this "preemptive" intervention, we believe such students are far more likely to remain at the university as engineering majors.

4. The course was fun to design and extremely rewarding to teach.

\section{Recommendations}

We offer several recommendations for faculty interested in creating a freshman multidisciplinary design experience. They are:

1. Encourage students to work together both inside and outside of scheduled class hours. 
2. Create multidisciplinary projects so as not to require the production or use of precision machinery. The appended project handout is one such example.

3. Design projects so that the level of analysis is not much beyond high school physics. The practice of engineering based mathematical principles may be brought to bear in terms of prediction of performance rather than failure analysis.

4. Maintain a schedule for both collecting logbooks and also commenting on logbook contents.

5. Provide a great deal of feedback to students in both written and verbal form on all components of design and discipline specific exercises.

6. Create opportunities for students to meet one-on-one with faculty members in the respective departments, and encourage their participation in department activities such as ASME or IIE.

7. Meet the class in a room outfitted with tables suitable for seating up to four students. Such a facility provides a convenient means for the design groups to interact among themselves and provides a similarly convenient place for the instructor to interact with the individual design teams.

8. Begin the semester with a frank discussion of the engineering attrition issue. Allow time and a forum during the semester for students to discuss their feelings with regard to pursuing a degree in engineering. Is the material and experience what the student had anticipated?

\section{Conclusion}

We have described a teaching situation and course design diametrically in contrast to the standard introductory lecture course. This new course design involves close, repeated interaction with each student in the class. Our ultimate goal was to create in the student a sense of belonging to, and contact with, a specific engineering department. Furthermore, this alternative approach to teaching the discipline-specific industrial or mechanical engineering freshman class is one positive step in the process of addressing our first year attrition rates. Last, the format of the new class more appropriately addresses both the ABET 2000 outcomes requirements and the feedback from our engineering alumni.

\section{Bibliography}

${ }^{1}$ Astin, A.W., What Matters in College: Four Critical Years Revisited, San Francisco, Jossey-Bass, 1993.

${ }^{2}$ Astin, A.W., “Engineering Outcomes”. ASEE Prism, September 1993, pp. 27-30.

${ }^{3}$ Astin, A.W., "The Climate for Undergraduate Engineering Education: Results from a Recent National Study". Address presented at the Annual Engineering Dean's Institute, New Orleans, March 29, 1993.

${ }^{4}$ Moller-Wong, C. and A. Eide, “An Engineering Student Retention Study”. Journal of Engineering Education, vol. 86, no. 1,1997 , pp. 7-15.

${ }^{5}$ Besterfield-Sacre, M., C.J. Atman, and L.J. Shuman, "Characteristics of Freshman Engineering Students: Models for Determining Student Attrition in Engineering”. Journal of Engineering Education, vol. 86, no. 2, 1997, pp. 139149. 
${ }^{6}$ Seymour, E. and N.M. Heweitt, Talking About Leaving-Factors Contributing to High Attrition Rates Among Science, Mathematics and Engineering Undergraduate Majors, Final Report to the Alfred P. Sloan Foundation on an Ethnographic Inquiry at Seven Institutions, Bureau of Sociological Research, University of Colorado: Boulder, April 1994.

${ }^{7}$ Tobias, S., They're Not Dumb, They're Different: Stalking the Second Tier. Research Corporation, Tucson, AZ, 1990.

${ }^{8}$ Cross, K.P., “On College Teaching”. Journal of Engineering Education, vol. 82, no. 1, 1993, pp. 9-14.

${ }^{9}$ Felder, R.M., K.D. Forrest, L. Baker-Ward, E.J. Dietz, and P.H. Mohr, “A Longitudinal Study of Engineering Student Performance and Retention I. Success and Failure in the Introductory Course". Journal of Engineering Education, vol. 82, no. 1, 1993, pp. 15-21.

${ }^{10}$ Felder, R.M., G.N. Felder and E.J. Dietz, “A Longitudinal Study of Engineering Student Performance and Retention V. Comparisons with Traditionally-Taught Students." Journal of Engineering Education, October 1998, pp. $469-480$.

${ }^{11}$ A Joint Project by the Engineering Deans Council and Corporate Roundtable of the American Society for Engineering Education, October 1994 Engineering Education for a Changing World.

${ }^{12}$ ASEE Engineering Deans Council/Corporate Roundtable. (1994) "Engineering Education for a Changing World". ASEE Washington, DC.

${ }^{13}$ Koen, Peter A. \& Kohli Pankaj. "ABET 2000: What are the most important criteria to the supervisors of new engineering undergraduates?” Annual Conference 1999; Session 3257.

${ }^{14}$ Evans, D.L., Beakley, G.C., Crouch, P.E., and Yamaguchi, G.T., (1993) "Attributes of Engineering Graduates and Their Impact on Curriculum Design”. Journal of Engineering Education, pp. 203-211.

${ }^{15}$ Benefield, L.D., Trentham, L.L., Khodadadi, K., Walker, W.F., (Jan 1997) “Quality Improvement in a College Engineering Instructional Program”. Journal of Engineering Education, pg. 57-68, January 1997.

${ }^{16}$ Saperstein, Lee. (1997) "Outcomes Measures and Performance Assessment: An Industrial Perspective”. National Conference on Outcomes Assessment.

${ }^{17}$ Lang, James D., Cruse, Susan, McVey, Francis D. and McMasters, John. (1999) "Industry Expectations of New Engineers: A Survey to Assist Curriculum Designers". Journal of Engineering Education. pp. 43-51.

${ }^{18}$ Besterfield-Sacre, Mary E., Wolfe, Harvey, Atman, Cynthia J. And Shuman Larry. "Development of CustomerBased Outcome Measures for an Engineering Program". ASEE Annual Conference 1999; Session 3530.

${ }^{19}$ Riley, Linda A. and Pines, Ed, "The Future is Here: Innovative Design Experiences for Industrial Engineers," ASEE Gulf Western Conference 2000.

\section{LINDA ANN RILEY}

Dr. Riley is Associate Department Head in the Department of Industrial Engineering at New Mexico State University. She teaches and researches in the areas of computational and simulation modeling, manufacturing systems, engineering logistics and freshman and senior multidisciplinary design courses. Prior to her teaching career, she was Director of a university-wide research center for seven years.

\section{EDGAR G. CONLEY}

Dr. Conley is a faculty member in the Department of Mechanical Engineering at New Mexico State University teaching and researching in the areas of experimental mechanics, design of machines and the freshman multidisciplinary introduction to design courses. He is advisor to the ASME student chapter in the College of Engineering. 


\section{Appendix 1 - Sample Project Handout}

\section{ME166/IE152 Fall 2000 - Design Project III}

\section{FROM EARTH TO THE MOON, ETC. - Jules Vern Catapult}

\section{Objectives of the Design Project}

1. Develop creative thinking skills

2. Practice teaming skills

a. Developing consensus

b. Understanding team member competencies

c. Defining the steps associated with completing the assignment

d. Assigning task responsibilities to each team member

e. Preparing team documents for submission

f. Creating a "team" product

g. Understanding the concept of concurrent engineering

h. Documenting the team experience in logbooks

i. Creating a team name and logo

j. Meeting deadlines

3. Reading and understanding specifications: achieving team consensus on taking written specifications to product prototype.

4. Evaluating various construction materials and production processes for strength and low weight. Documenting the evaluation process.

5. Developing a prototype machine to meet specifications.

6. Testing your prototype machine in trial runs to optimize the design.

7. Preparing supporting documents for the machine design.

8. Demonstrating in a class setting that your catapult meets the required specifications.

9. Submitting a full design package and prototype machine.

\section{Your Team's Challenge}

\section{Summary}

The Jules Vern Catapult Manufacturing Company wishes to market reliable machinery that has the capability to hopscotch across the solar system using a series of lightweight but powerful catapults. Your engineering team's task is to design and create a light weight catapult prototype, powered solely by two official Aggie Racing rubber bands, that will launch all other design teams' catapult as far as possible.

As is common in engineering practice, the design process as well as the machinery itself must be well documented. Thus, a series of design drawings, bills of material, exploded product diagrams, manufacturing supplier information, assembly precedence charts, cost information and launch modeling equations, will support the catapult design itself.

The performance of your catapult will be evaluated in a round robin trial with all other designs. Each team will launch all other catapults. Your team score will be the sum of the distances you launch all 
other catapults times the sum of the distances your own catapult is launched. See the example scorecard below.

\section{Design Specifications}

1. Your team must incorporate the supplied $3 \times 3 x^{1 / 2}$ (approximate) inch wood platform into your catapult. This platform will serve as the launching base, so it must be located on the catapultlaunching arm.

2. Your catapult must measure less than $40 \mathrm{~cm}$ in any direction.

3. You may use any materials to construct your catapult.

4. All catapults must be powered by official Aggie Racing rubber bands, used for the preliminary prototype demonstration and for the final trial. Rubber bands may be obtained exclusively from the instructors.

5. You must incorporate a convenient means to replace the rubber bands with fresh ones.

6. Burning through a length of thread (with a cigarette lighter) must trigger your catapult. Therefore you must incorporate a convenient means so the launching arm may be cocked and tied with thread. The catapult is to be triggered without contacting either the launcher or the launchee with your hands.

7. You may not modify your catapult in between trials but minor repairs are allowed.

8. Your catapult must balance (hands off) on a standard $3 \times 3 x^{1 / 2}$ wood platform.

\section{Responsibilities}

As either a ME or IE team member, you fulfill shared as well as specific project responsibilities as indicated below.

1. Team name and logo.

\section{Shared}

2. Design timeline and support package.

3. Anything else you need to do to make your team score high in the trial.

ME

1. Design the catapult; produce a hand sketch of your device before you begin construction.

2. Construct the machine carefully using good craftsmanship; do this early in the three-week period scheduled for this project.

3. Test the catapult in a safe place. Stretched-tight rubber bands store a surprisingly large amount of energy so you must be careful, especially of your eyes, when stretching the rubber bands and when you trigger your mechanism.

\section{IE}

1. Create the catapult design drawings in ProE or AutoCad based on the final design concept from the MEs.

2. Determine a full bill of materials for manufacturing the catapult.

3. Draw an exploded product diagram.

4. Illustrate the assembly process of the catapult with an assembly precedence diagram.

5. Using the Thomas Register, identify a minimum of five suppliers for each component of the catapult design.

6. Brainstorm on equations and methods of modeling how far the catapult will launch. 


\section{Project Evaluation}

Each ME/IE group will have the opportunity to earn 100 points with 50 points generated from the ME responsibility areas and 50 points generated from the IE responsibility areas.

\section{ME primary responsibility areas: 50 points}

5 points if your catapult will balance in a standard plywood platform just prior to the Preliminary Prototype Demonstration.

10 points (maximum) based on the distance your catapult will launch a standard 180 gram weight divided by the catapult's own net weight (including two Aggie rubber bands) at the Preliminary Prototype Demonstration.

5 points provide IE team members with final design and assembly plans by deadline (Monday 12/4, 11:59 PM)

30 points (maximum) for Final Trial score

A sample scorecard for the Final Trial for four design groups would look like this:

\begin{tabular}{|c|c|c|c|c|c|c|}
\hline Launchers & Launchees $\Longrightarrow$ & Group 1 & Group 2 & Group 3 & Group 4 & $\begin{array}{l}\text { row } \\
\text { sum }\end{array}$ \\
\hline Group 1 & & $\mathrm{X}$ & 3 & 4 & 6 & 13 \\
\hline Group2 & & 2 & $X$ & 8 & 4 & 14 \\
\hline Group 3 & & 6 & 8 & $X$ & 1 & 13 \\
\hline Group 4 & & 7 & 6 & 1 & $\mathrm{X}$ & 17 \\
\hline column sum & & 15 & 17 & 13 & 11 & $\mathrm{X}$ \\
\hline
\end{tabular}

Example score for Group 2: 17 x $14=198$

Report containing:

\section{IE primary responsibility areas: 50 points}

Catapult design drawings with discussion of the design process: 10 points

Bill of materials for manufacturing the catapult: 10 points

Exploded product diagram: 5 points

Assembly precedence diagram: 10 points

Thomas' Register: 5 points

Equations and methods of modeling how far the catapult will launch: 10 points

\section{Project Schedule}

1. Project assignment Friday 11/17

2. Respective task plans, team name, and logo, due at class time on Monday 11/20

3. Preliminary Prototype Demonstration, Wednesday 11/29

4. Final design and assembly plans provided to IE team members by Monday 12/4

5. Final Prototype Trial, to take place in sand lot adjacent to Jett Hall, Wednesday 12/6

6. Report due Friday $12 / 8$ at class time. 


\section{Appendix 2 - Report Outline for Catapult Project}

\section{Checklist for Final Design Report}

A title page with the name of your group, group member names and a title of your report that captures the catapult design experience. Each team member should sign the front cover of the report indicating full participation in the group activities.

A section discussing the four-step design process. Using the Four-Step Design Process as an outline, briefly discuss the design process that your group used in order to generate the catapult. For example, how did your group brainstorm to discuss ideas concerning the catapult design? What was most important to your team in creating the catapult? Also, during the synthesis portion of the design process, which alternative materials were discussed and which material was chosen, and for what reasons? During the analysis phase, that is, after your first prototype was built (or in the stages of being built), did your group discuss any alternative methods of creating or manufacturing the catapult? What processes or methods did you use to assure that your catapult would pass the various tests before the final tests? Finally, if you were to undertake a similar project in the future, how would your approach be different from the present experience?

A section discussing your team test results in the testing of the catapult. For example, did you perform any of the tests before submitting the catapult to final testing? What exactly were the results? (We have given this results file to you in an Excel format as well as in a paper copy.)

A copy of your task plan - Did you keep on schedule? If not, where did you fall behind? Were there any issues or challenges involved with working in teams?

$\square$ Design drawings of the catapult. Include your catapult design drawings created in ProE or AutoCad based on the final design concept from the MEs.

$\square$ A full bill of materials for manufacturing the catapult. Present the bill of materials in a table or matrix form showing part name, number, quantity needed, material, size and any other information you wish to include.

A drawing of an exploded product diagram (product structure diagram). Use PowerPoint or a similar program.

An indented bill of materials from the exploded product diagram.

An illustration of the assembly process of the catapult created in an assembly precedence diagram.

$\square$ From Thomas's Register, identify and provide a minimum of five suppliers for each component of the catapult design. Include the printouts with the report.

$\square$ Include any ideas on equations and/or methods of modeling how far the catapult will launch.

Last, remember to include the digital pictures taken in class of your catapult and emailed to you. Use these pictures throughout the report to better illustrate points you wish to make. 